\title{
Aberrant pancreatic tissue in a giant mediastinal cyst: an uncommon entity
}

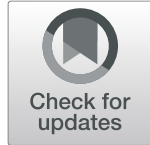

Josiah Miner Njem ${ }^{3^{*}} \mathbb{D}$, Benjamin Ugwu ${ }^{3}$, John Collins ${ }^{1}$, Innocent Emmanuel², Ojile Akpa Philip ${ }^{2}$ and John Awodi ${ }^{3}$

\begin{abstract}
Background: Heterotopia of pancreatic tissue in the thorax and mediastinum is uncommon, although, a common developmental anomaly in the gastrointestinal tract where the aberrant tissue is a component of gastrointestinal duplication cysts, intralobular pulmonary sequestration or teratomas.

Case presentation: We report a case of an ectopic pancreas located in a giant mediastinal cyst in a 2-year old girl who presented with severe dyspnoea due to external compression of the intra-thoracic structures, mainly the right main bronchus. Surgical resection was carried out with complete relief of symptoms. The cyst was confirmed histopathologically to contain pancreatic tissue. Literature review showed that this is an uncommon presentation hence the need to report the case.
\end{abstract}

Conclusion: Heterotopia of the pancreas although, an uncommon occurrence in the thorax and mediastinum, should be considered when dealing with cystic lesions of the mediastinum and surgery plays an important role in its management.

Trial registration: JUTH/DCS/ADM/127/XXV/203. Registered 2nd September 2018.

Keywords: Mediastinal cyst, Heterotopic pancreatic tissue

\section{Introduction}

Heterotopic pancreas, also known as aberrant or ectopic pancreas, is pancreatic tissue which has no anatomic and vascular continuity with the main body of the pancreas [1-5]. Congenital ectopia of pancreatic tissue although, a common developmental anomaly in the gastrointestinal tract, its occurrence in the thorax and mediastinum is uncommon [1-3]. ,Aberrant pancreatic tissue in the anterior mediastinum was first described pathologically by Klob in 1859 and first published by Shillitoe and Wilson in 1957 [4, 6, 8]. When found in the thorax, the pancreatic tissue is mostly a component of gastroenteric duplication cysts, intralobular pulmonary sequestration or teratomas [1, 4-8]. This anomaly has been reported in approximately $2 \%$ of autopsies and $70-90 \%$ of these were located in the gastrointestinal tract mainly in the stomach, duodenum, jejunum and ileum [1-3]. The aetiology of this anomaly is unclear, there are two theories regarding its embryogenesis $[5,6]$. The first theory

\footnotetext{
*Correspondence: njemjoe@gmail.com

${ }^{3}$ Cardiothoracic Surgery Unit, Department of Surgery Jos University Teaching Hospital, Jos, Nigeria

Full list of author information is available at the end of the article
}

involves abnormal differentiation of the pluripotent epithelial cells of the ventral primary foregut resulting in the formation of ectopic pancreatic tissues in the mediastinum [5-8]. This was supported by the fact that the pancreas and lower respiratory tract, share the same embryological origin from the primitive foregut. The second theory involves migration of cells from the pancreatic bud to the different sites [6].

Clinical presentations are non-specific and essentially result from compression of intra-thoracic structures, thus, symptoms such as cough and dyspnoea due to compression of the major airway may occur. Hypoglycaemia has also been reported in patients with ectopic pancreatic tissue in the mediastinum [4]. We carried out Pub med search to find all the reported cases of ectopic, heterotopic or aberrant pancreatic tissue in the mediastinum and found that in addition to the index patient, there were thirty reported cases of aberrant pancreas in the mediastinum (Table 1). Most of the cases described were in young adults, the average age was 29 years. The index patient was a two year old girl. The prevalence was higher in females (58\%). Aberrant 
Table 1 Ectopic pancreas in the anterior mediastinum- A report of 30 patients $[6,8]$

\begin{tabular}{|c|c|c|c|c|c|}
\hline SN & Reference & Gender & Age (years) & Size $(\mathrm{cm})$ & Pathology \\
\hline 1 & Shillitoe etal 1957 & $\mathrm{~F}$ & 15 & 5.5 & benign \\
\hline 2 & Carr et al. 1977 & $\mathrm{~F}$ & 57 & 10 & benign \\
\hline 3 & Von Schweinitz et al. 1990 & M & 5 & $5 \times 5 \times 5$ & benign \\
\hline 4 & Perez-Ordonez et al. 1996 & $\mathrm{~F}$ & 16 & 12 & benign \\
\hline 5 & Gong et al. 1997 & $\mathrm{~F}$ & 26 & $20 \times 15$ & benign \\
\hline 6 & Gong et al. 1997 & $\mathrm{~F}$ & 26 & $4.3 \times 1.3$ & benign \\
\hline 7 & Wu et al. 1998 & $\mathrm{~F}$ & 60 & $10 \times 15$ & benign \\
\hline 8 & Cagirici et al. 2001 & $\mathrm{~F}$ & 45 & $10 \times 8$ & benign \\
\hline 9 & Sentis et al. 2004 & M & 44 & $10 \times 8 \times 7.5$ & benign \\
\hline 10 & Yamato et al. 2005 & M & 39 & $10 \times 8$ & benign \\
\hline 11 & Al-Salam et al. 2006 & M & 40 & $8 \times 6 \times 6$ & benign \\
\hline 12 & Wang et al. 2007 & M & 17 & $12 \times 12 \times 4$ & benign \\
\hline 13 & Wang et al. 2007 & $\mathrm{~F}$ & 24 & $10 \times 8 \times 4$ & benign \\
\hline 14 & Ehricht et al. 2009 & M & 25 & $15 \times 15$ & benign \\
\hline 15 & Chen et al. 2009 & $\mathrm{~F}$ & 32 & $13 \times 16 \times 8$ & benign \\
\hline 16 & Fayoumi et al. 2010 & M & 51 & $10 \times 7 \times 5$ & benign \\
\hline 17 & Fayoumi et al. 2010 & M & 42 & $10 \times 5$ & benign \\
\hline 18 & Takemura et al. 2011 & $\mathrm{~F}$ & 21 & $3.5 \times 3.5$ & benign \\
\hline 19 & Sandor et al. 2012 & M & 32 & $4 \times 4$ & benign \\
\hline 20 & Byun CS et al. 2012 & $\mathrm{~F}$ & 31 & $7 \times 3 \times 4$ & benign \\
\hline 21 & St Romain et al. 2012 & $\mathrm{~F}$ & 66 & $11 x$ & malignant \\
\hline 22 & Rokach et al. 2013 & $\mathrm{~F}$ & 22 & $5.1 \times 3.8 \times 2.3$ & benign \\
\hline 23 & Zhang et al. 2014 & M & 15 & $7 \times 4.5$ & benign \\
\hline 24 & Zhang et al. 2014 & $\mathrm{~F}$ & 16 & 6 & benign \\
\hline 25 & Li et al. 2014 & M & 18 & $16 \times 12 \times 9$ & benign \\
\hline 26 & Sibel et al. 2014 & M & 23 & $6 \times 8$ & benign \\
\hline 27 & Koh et al. 2015 & M & 17 & $7.5 \times 7 \times 5.5$ & benign \\
\hline 28 & Wu et al. 2015 & $\mathrm{~F}$ & 45 & $7.5 \times 7 \times 5.5$ & benign \\
\hline 29 & Mansi et al. 2017 & $\mathrm{~F}$ & 29 days & $5 \times 4 \times 3.5$ & benign \\
\hline 30 & Snak et al & $\mathrm{F}$ & 21 & $6.7 \times 7.5$ & benign \\
\hline 31 & Index case & $\mathrm{F}$ & 2 & $20 \times 16 \times 3.5$ & benign \\
\hline
\end{tabular}

pancreas in the mediastinum is uncommon and to the best of our knowledge thirty cases have been documented in the literature (Table 1). We report an uncommon clinical case of a giant mediastinal cyst containing aberrant pancreatic tissue.

\section{Case report}

A 2-year old girl was referred to the Jos University Teaching Hospital in north central Nigeria, with complains of progressive cough and difficulty in breathing in the preceding six months. She was treated at several health facilities for pneumonia and asthma without resolution of symptoms. Patient had no fever or features suggestive of tuberculosis. Pregnancy, delivery, neonatal and infant periods were uneventful and patient had received all immunization appropriate for her age. Examination at presentation showed a child in severe respiratory difficulty necessitating oxygen administration, with Spo $289-90 \%$ at room air and 96\% on oxygen by nasal prongs. There was bulging of the right side of her anterior chest wall and markedly reduced breath sounds on the right hemithorax. No features suggestive of congenital heart disease. Chest X-ray showed homogenous opacity continuous with the cardiac silhouette, involving almost the entire right thoracic cavity with a shift of the mediastinum to the left (Fig. 1). 


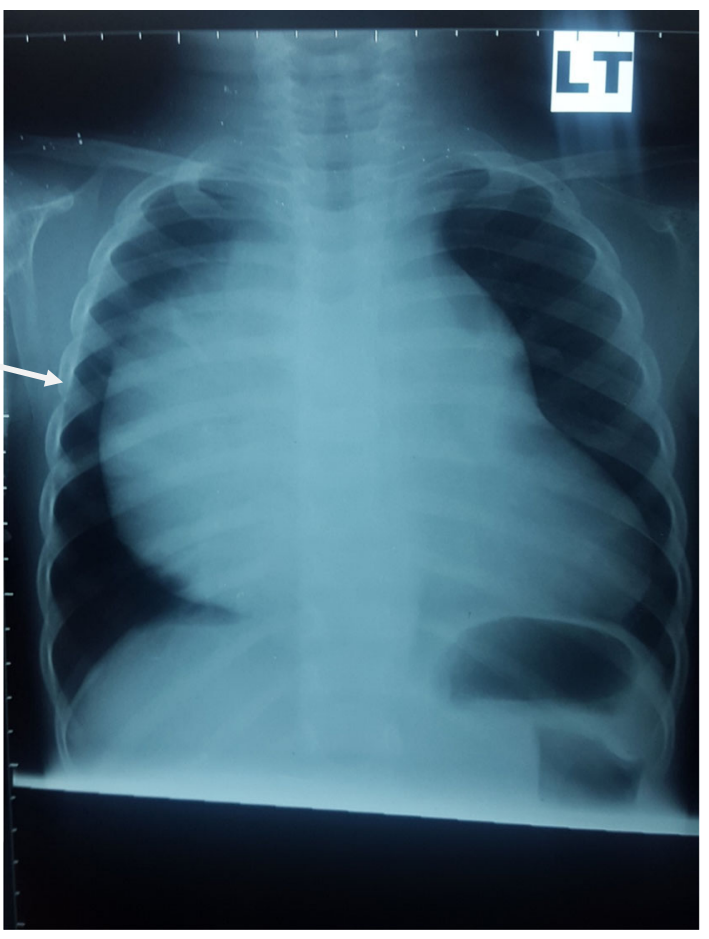

Fig. 1 Chest X-ray showing widdened mediastinum(arrow) and homogenous opacity continous with the cardiac silhouette (arraw)

Echocardiography confirmed a very large well defined mediastinal cyst compressing the right atrium, left atrium and right ventricle (Fig. 2). Contrast-enhanced computed tomography scan of the chest showed a well defined large cyst of the anterior mediastinum compressing the right main bronchus (Fig. 3). Blood investigations were all normal. A diagnosis of anterior mediastinal cyst was made and the patient had right posterolateral thoracotomy through the fifth intercostals space. Intraoperatively a large tense cyst measuring $20 \times$ $16 \times 3.5 \mathrm{~cm}$ was noted adjacent to the pericardium and attached loosely to the thymus compressing but not attached to the bronchus. The cyst was unilocular with a thick wall and contained serous fluid (Figs. 4 \& 5); the cyst was excised en bloc. There was moderate pericardial fluid which was drained by a pericardiostomy. Histopathological sections showed ectopic pancreatic tissues in the wall of the cyst (Figs. 6, 7 and 8). The post operative course was uneventful; the patient has been asymptomatic after a followed-up period of twenty four months.

\section{Discussion}

Pancreatic heterotopia, also referred to as ectopic or aberrant pancreas is pancreatic tissue that has no anatomic or vascular connection with the main body of the pancreas [2-6]. This anomaly has been reported in

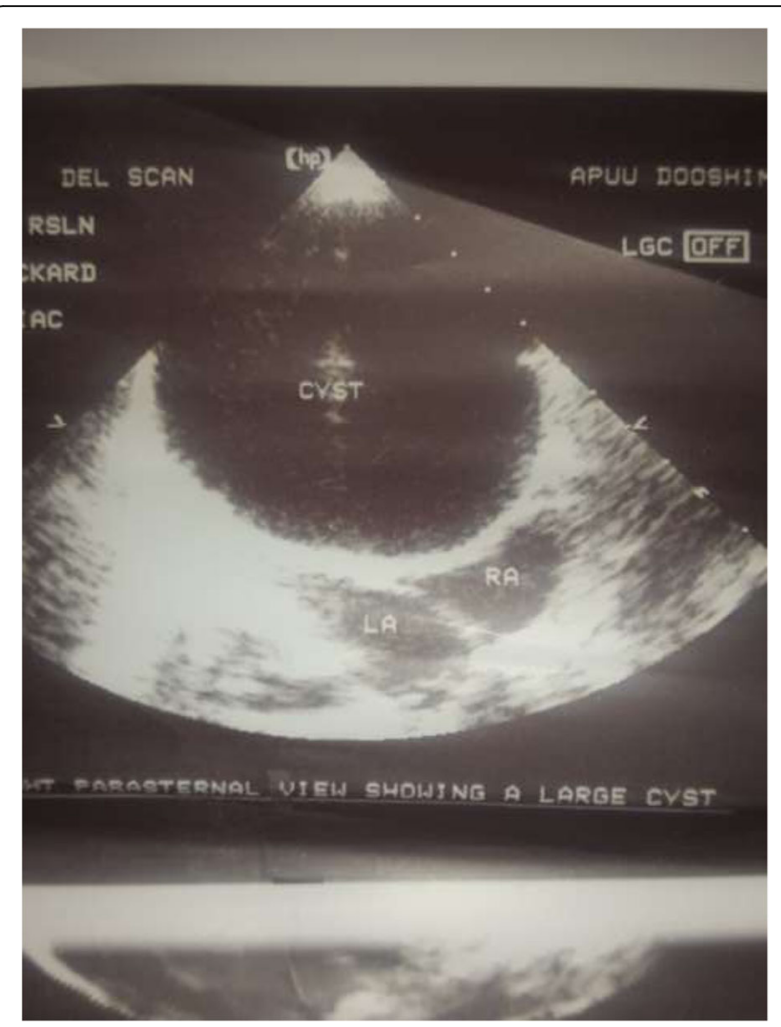

Fig. 2 Echocardiography showing the cyst

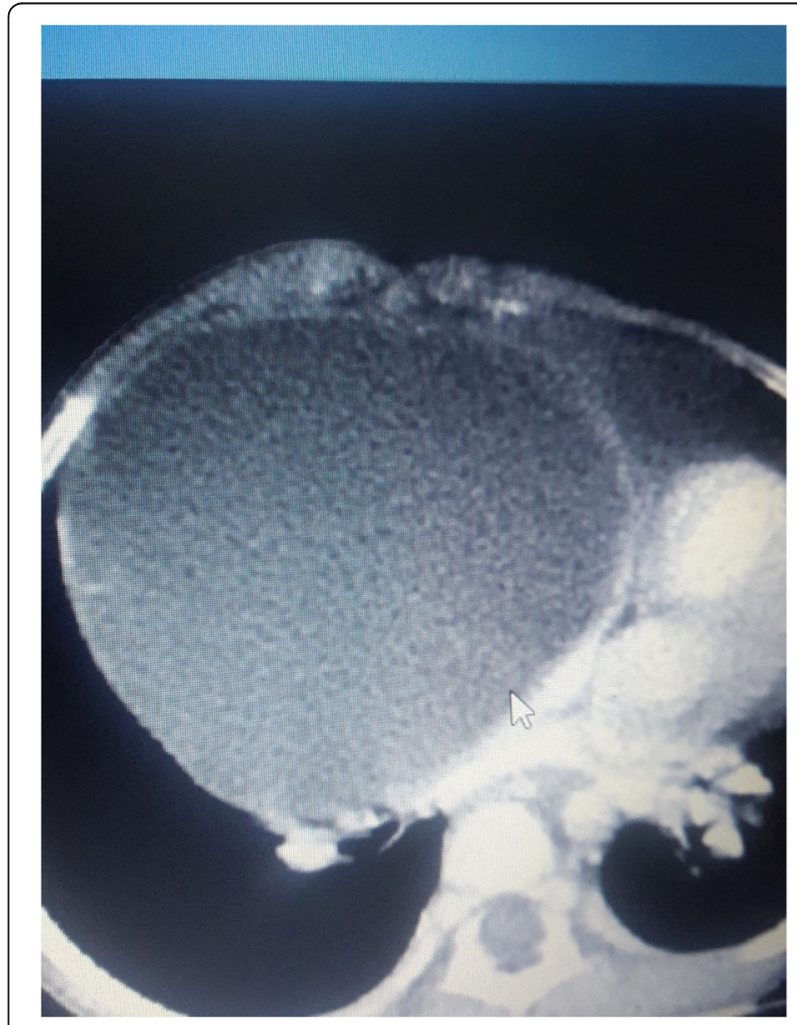

Fig. 3 Contrast CT scan showing the cyst(white arrow) 


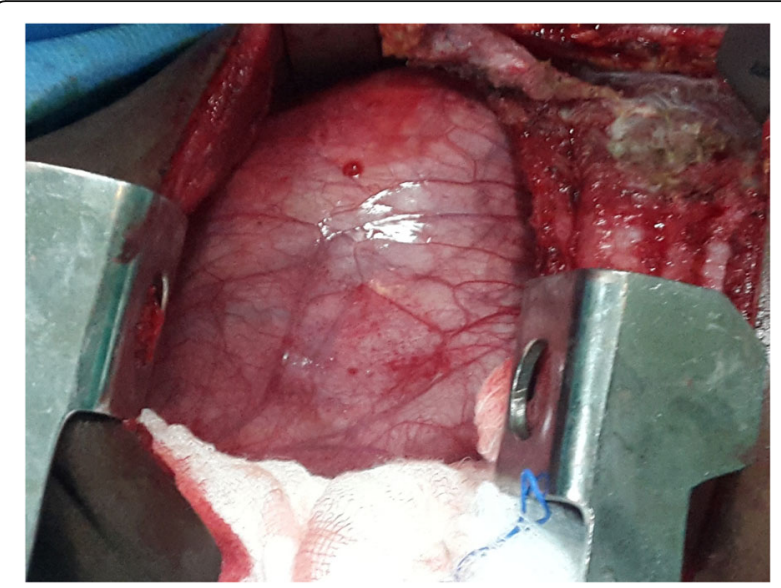

Fig. 4 Intra-operative picture of the cyst(arrow)

approximately $2 \%$ of autopsies and $70-90 \%$ of these are located in the gastrointestinal tract mainly in the stomach, duodenum, jejunum and ileum [1-3]. Congenital ectopia of pancreatic tissue in the thorax and mediastinum is quite uncommon and occurs mostly in adults, with a slight female preponderance [1-12]. The index patient was a two old year girl.

The clinical presentation was usually non specific, related to the size and location of the lesion as well as the presence of inflammation or malignant transformation within the cyst. The patients usually present with features such as cough, shortness of breath, chest pain, fatigue, shoulder pain, fever, night sweats, and pulmonary infiltrates, pleural and pericardial effusion [3, 5-10]. The index patient presented with shortness of breath, cough, homogenous opacity on chest radiograph and pericardial effusion. We considered these symptoms to be due to compression of adjacent structures by the large cyst, since symptoms completely resolved following surgical

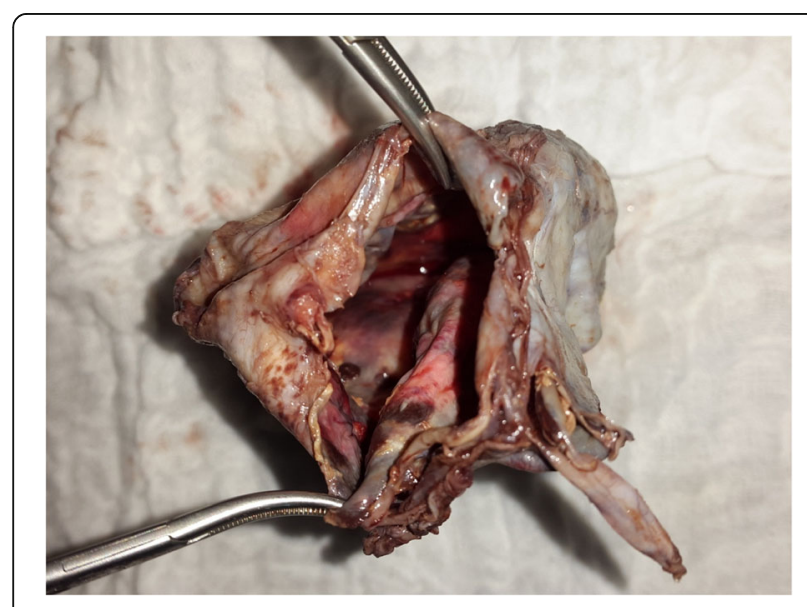

Fig. 5 Cyst after immersion in formalin

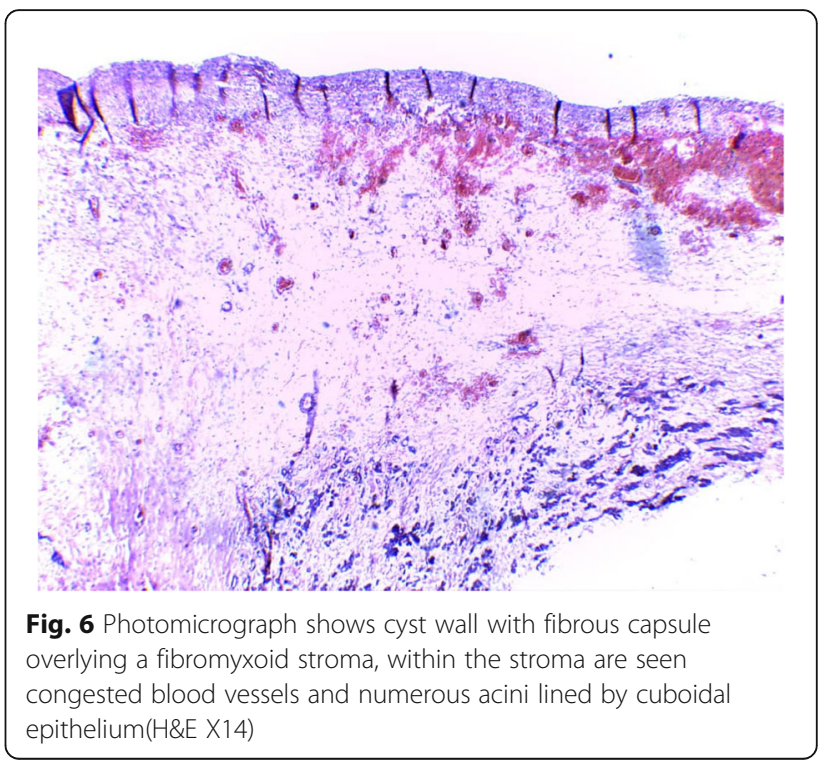

excision of the cyst and patient has remained asymptomatic at follow-up.

Contrast-enhanced computed tomography scan and echocardiography were useful in the diagnosis of mediastinal cysts. There were however, no specific features on either of these imaging modalities to distinguish ectopic pancreatic tissue from other cystic lesions of the mediastinum. Most cases were benign and had complete resolution of symptoms after surgery, with no recurrence [6-12]. The index patient had complete resolution of symptoms and has remained asymptomatic at follow-up. The histopathology showed benign cystic lesion containing ectopic pancreas. This underscores the importance of surgery in the management of this lesion, which could prevent malignant changes as well as relieving pressure on adjacent structures.

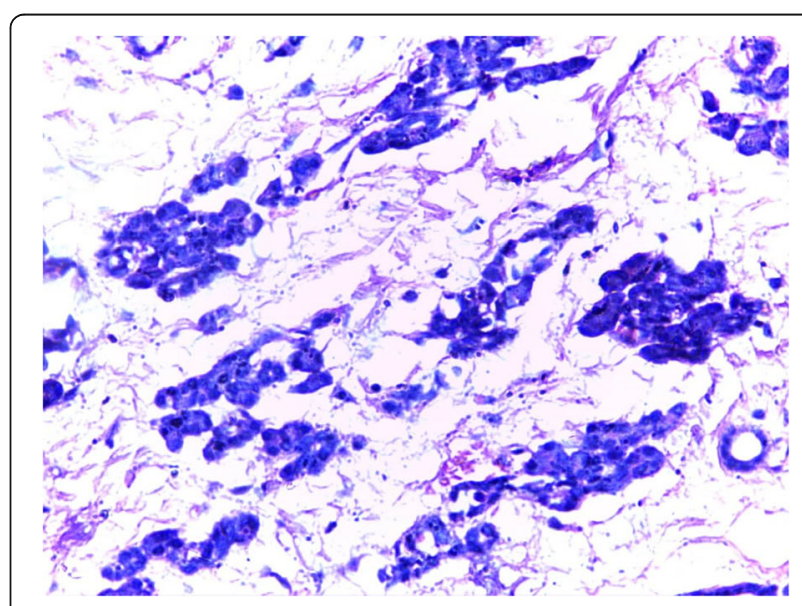

Fig. 7 Acini lined by cuboidal epithelial cells with small round to oval nuclei with basophilic cytoplasm (H\&E X10) 


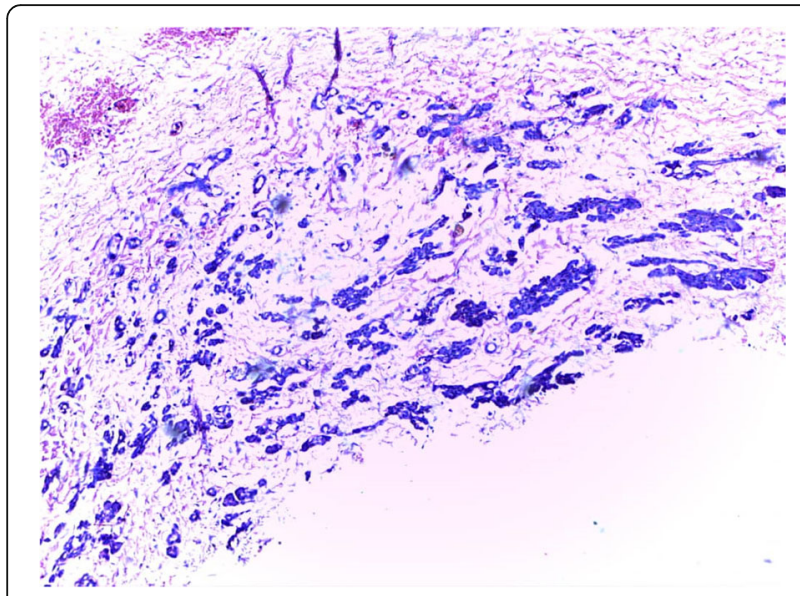

Fig. 8 Acini with fibromyxoid stroma lined by cuboidal epithelium with small oval nuclei and basophilic cytoplasm (H\&E X40)

\section{Conclusion}

Pancreatic heterotopia should be considered in the differential diagnosis of mediastinal cyst. Most mediastinal cyst containing ectopic pancreatic tissues are benign and surgical resection results in complete resolution of symptoms, thus strengthening the importance of surgery in the management of this lesion.

\section{Acknowledgements \\ Not applicable.}

\section{Data sharing}

Not applicable to this article as no data set were generated or analysed during the current study.

\section{Authors' contributions}

$\mathrm{NJ}$ - Was the lead surgeon, designed and wrote the manuscript as well as approval of the final copy of the manuscript. U B - Participate in the surgery, design and writing of the manuscript, as well as approval of the final copy of the manuscript. C J - Referring paediatrician, participated in the design and writing of the manuscript as well as approval of the final copy of the manuscript. I E - Carried out pathological examination of the surgical specimen, read the histologic slides and final approval of the manuscript. O A - Carried out pathological examination of the surgical specimen, read the histologic slides and final approval of the manuscript. A J - Participate in the surgery, design and writing of the manuscript, as well as approval of the final copy of the manuscript.

\section{Funding}

None.

\section{Availability of data and materials \\ not applicable.}

\section{Ethics approval and consent to participate}

Institutional clearance was obtained from the ethical committee of the hospital as well as informed consent from the parents of the patient.

\section{Consent for publication}

Written informed consent was obtained from the parents of this patient for the publication of this article and any accompanying images.

\section{Competing interests}

The authors declare that they have no competing interests.

\section{Author details}

'Department of Paediatrics, Jos University Teaching Hospital, Jos, Nigeria. ${ }^{2}$ Department of Pathology \& Morbid Anatomy, Jos University Teaching Hospital, Jos, Nigeria. ${ }^{3}$ Cardiothoracic Surgery Unit, Department of Surgery Jos University Teaching Hospital, Jos, Nigeria.

Received: 26 October 2018 Accepted: 25 June 2019

Published online: 08 July 2019

\section{References}

1. Sandor S, Laszlo L, Tamas T, Edit V, Zsofia V. Ectopic pancreatic tissue appearing in a mediastinal cyst. J Cardiothorac Surg. 2012;7:22.

2. Kye WK, Kyung YJ, Woo IY. A pancreatic cyst of the anterior mediastinum. Korean J Pathol. 1998;32(11):1025-7.

3. Meha M, Nidhi M, Sonam M, Gupta GR, Anup M. Aberrant Pancreatic Tissue in a Mediastinal Duplication Cyst. A Rarity with Literature Review. Case Reports in Gastrointestinal Medicine. 2017;7294896(4).

4. Yamato T, Makoto T, Keiji K, Shigeki T. Ectopic pancreas in the anterior mediastinum. J Thorac and Cardiovasc surg. 2005;53(9):498-501.

5. Lizhi Z, Li-Qing P, Jian-Qun Y, Hong-Mei Y, Zhi-Gang C, Han-Jiang Z, et al. Oncol Lett. 2014;7(4):1053-6.

6. Hyun MK, Jee WC, Sun YJ, Chang LH, Young SK, Bo GJ, et al. Ectopic pancreas presenting as a solid mediastinal mas. Int J Surg Pathol. 2015;23(7): 585.

7. Anagnostou E, Soubas V, Agakidou E, Papaconstantinou C, Antonitsis P, Leontsini M. Paediatr Pulmonol. 2009:44(12):1240-3.

8. Brian TC, Dai HC. Retrocardiac mediastinal foregut duplication cyst. J Paediatr Surg. 2016;14:45-8.

9. Yosinta S, Ery KD, Auliya BS, Rovi P, A fif R, Ahmad G, et al. Mediastinal ectopic pancreas with abundant endocrine cells co-existing with mediastinal cyst and Thymic hyperplasia. Hindawi Case Reports in Pathology. 2018; Article ID 8270516, 6 Pages.

10. Rokach A, Izbiki G, Deeb M, Bogot N, Arish N, Hadas-Halperen I, et al. Ectopic pancreatic pseudocyst and cyst presenting as a cervical and mediastinal Mass. Case report and review of the literature. J Diagnost pathol. 2013;8(1):176.

11. Jeung M, Gasser B, Gangi A, Bogorin A, Charneau D, Wihlm JM, et al. Imaging of cystic masses of the mediastinum. Home Radiographic. 2002; 22(1):79.

12. Cagirici U, Ozbaran M, Veral A, Posacioglu H. Ectopic Medistinal pancreas. European J Cardio-thorac Surg. 2001;19:514-5.

\section{Publisher's Note}

Springer Nature remains neutral with regard to jurisdictional claims in published maps and institutional affiliations.

Ready to submit your research? Choose BMC and benefit from

- fast, convenient online submission

- thorough peer review by experienced researchers in your field

- rapid publication on acceptance

- support for research data, including large and complex data types

- gold Open Access which fosters wider collaboration and increased citations

- maximum visibility for your research: over $100 \mathrm{M}$ website views per year

At $\mathrm{BMC}$, research is always in progress.

Learn more biomedcentral.com/submission 